\title{
ANCISTROCLADUS BENOMENSIS (ANCISTROCLADACEAE): A NEW SPECIES FROM PENINSULAR MALAYSIA
}

\author{
H. RISCHER ${ }^{1,2,5}$, G. HEUBL ${ }^{3}$, H. MEIMBERG ${ }^{3}$, M. DREYER ${ }^{2}$, H.A. HADI ${ }^{4}$ \\ \& G. BRINGMANN 1,5
}

\begin{abstract}
SUMMARY
Ancistrocladus benomensis Rischer \& G. Bringmann, a new species from Gunung Benom, Malaysia is described and illustrated. Diagnostic notes concerning morphology, occurrence of specific naphthylisoquinoline alkaloids, and support from molecular analyses are provided.
\end{abstract}

Key words: Ancistrocladus benomensis, Ancistrocladaceae, Gunung Benom, Malaysia.

\section{INTRODUCTION}

The monotypic genus Ancistrocladus Wall. (Ancistrocladaceae) comprises approximately 20 species (Gereau, 1997) and is characterized by a disjunct distribution in the palaeotropics with two areas of speciation, one in tropical West and Central Africa and one in South East Asia. All taxa are scandent shrubs or woody lianas with tendrillike modified shoots provided with characteristic circinate woody hooks as climbing devices.

Recently a synoptic revision of the African taxa of the genus Ancistrocladus has been presented by Cheek (2000), with an identification key and detailed information concerning taxonomy, distribution, and ecology of the 13 species recognized. For the Asian taxa an equivalent comprehensive study is still lacking and there is much uncertainty in the delimitation of taxa as well as on ecological preferences, seed set, pollination, and flowering rhythm.

Concerning taxonomy one has to refer to a synopsis presented by Gilg (1925) and to an annotated checklist of species which was compiled by Gereau (1997) based on a survey of local floras. In this latter overview a detailed account on the typification for 25 binominals is presented, including 12 valid species recognized by the author for South East Asia: A. attenuatus Dyer, A. carallioides Craib, A. cochinchinensis Gagnep., A. extensus Wall. ex Planch., A. griffithii Planch., A. hainanensis Hayata, A. hamatus

1) Institute of Organic Chemistry, Julius-Maximilians University Würzburg, Am Hubland, 97074 Würzburg, Germany.

2) Present address: VTT Biotechnology, Tietotie 2, 02044 Espoo, Finland.

3) Department Biology I, Section: Biodiversity Research, Systematic Botany, Ludwig-Maximilians University Munich, Menzinger Str. 67, 80638 München, Germany.

4) Chemistry Department, Faculty of Science, University of Malaya, Jalan Pantai Baru, 50603 Kuala Lumpur.

5) Corresponding authors (e-mail: heiko.rischer@vtt.fi and bringman@chemie.uni-wuerzburg.de). 
(Vahl) Gilg, A. harmandii Gagnep., A. heyneanus Wall. ex J. Graham, A. tectorius (Lour.) Merr., A. wallichii Planch., and A. thwaitesii Tiegh. (according to Harriman (1987) probably a synonym of A. hamatus), neglecting A. stelligerus Wall. ex A.DC. and considering $A$. vahlii Arn. as a synonym of A. hamatus. Contrary to this taxonomic concept, Van Steenis (1948) had previously lumped all species from South East Asia under A.tectorius (Lour.) Merr. because of difficulties distinguishing vegetative material.

Indeed, the Ancistrocladus tectorius complex exhibits a wide range of variation in morphological features and its elements have never been comprehensively examined with respect to their taxonomic delimitations. Especially the lack of floral and fruit characters which are of significant diagnostic value, complicates the delimitation of species. This is due to the fact that many Ancistrocladus taxa climb in rather tall trees and have small inconspicuous flowers that wither very rapidly. There is also the fact that most species treated are known only from a few localities, which is reflected in nearly all revisions (Cheek, 2000) and floristic treatments (Van Steenis, 1948). The situation is indeed even more complicated because all Asian species have been collected and described before 1925, often in vegetative state only, the type specimen of A. tectorius even dates back to 1790 (basionym Bembix tectoria Lour.) and consists only of poor fragments (Moore \& Tandy, 1927).

Originally doubts about the 'one-species concept' of Van Steenis (1948) arose from comparing phytochemical studies of 'A. tectorius' material collected from geographically disjunct areas, e.g., in Hainan (Chen et al., 1981; Bringmann \& Kinzinger, 1992; Tang et al., 2000), Laos (Foucher et al., 1975), Central Thailand (Ruangrungsi et al., 1985), Southern Thailand (Manfredi et al., 1996), and Southern Peninsular Malaysia (Montagnac et al., 1995). The strong geographical correlation of the observed structures and the yet different naphthylisoquinoline alkaloid spectrum of $A$. cochinchinensis from the type location in Vietnam (Nguyen et al., 1997) hint at the occurrence of several separate species. In addition, the examination of Ancistrocladus using molecular markers indicates that the A. tectorius complex could be split into at least 9 species in South East Asia. Detailed results will be published elsewhere (Meimberg et al., submitted).

A rich collection of Ancistrocladus plants from different sites in South East Asia is meanwhile in cultivation at the Botanical Garden of Würzburg to study seedling and flower development including phytochemical composition and biosynthesis under controlled conditions. This collection is the basis for the description of further species indicated by molecular methods. The availability of flowers from A. benomensis in the greenhouse (export permit no. WKL00/149) is a first success in our effort to gain basic biological data for the Ancistrocladus complex in South East Asia.

\section{MOLECULAR DATA}

In a phylogenetic analysis using sequences of the internal transcribed spacers (ITS1 and ITS2, nuclear rDNA) and the trnK intron (chloroplast DNA), A. benomensis differs in both markers from Ancistrocladus samples from all over South East Asia ( 75 samples from 24 locations were investigated, details will be published elsewhere). The ITS sequence of $A$. benomensis was equal in all four samples investigated and shows at least 
eight different positions to the other samples, while the most closely related sequence is from a sample from South East Thailand, c. $850 \mathrm{~km}$ away. This relationship was also indicated using similarity analysis of Inter Simple Sequence Repeat PCR (ISSR). The trnK intron sequence shows at least four different positions to the other samples, while the most similar sequence is from a sample from Southern Malaysia.

\section{CHEMOTAXONOMIC DEMARCATION}

Phytochemical investigations (Bringmann et al., 2004) of bark and leaf material of $A$. benomensis with respect to its characteristic natural products, the naphthylisoquinoline alkaloids (Bringmann \& Pokorny, 1995), revealed that the plant is unequivocally different from all the other known Ancistrocladus species, in particular from the only known Malaysian one, A. tectorius (Montagnac et al., 1995). Thus, it possesses the highest number of fully dehydrogenated naphthylisoquinoline alkaloids ever isolated from any other known Ancistrocladus species, among them the first optically active fully aromatized naturally occurring Dioncophyllaceae-type (Bringmann \& Pokorny, 1995) alkaloids (i.e., without an oxygen function at C-6). Another unique feature of the new species is the isolation of the first fully aromatized naphthylisoquinoline alkaloids with a hydroxymethylene group at C-3 (Bringmann et al., in press).

\section{DESCRIPTION}

Based on evidence from different sources we provide a description of an phytochemically unusual Ancistrocladus species discovered in 1999 from an isolated mountain of Peninsular Malaysia based on complete material including all stages of flowering and fruits, which is morphologically, phytochemically, and genetically distinguishable from all other South East Asian species.

\section{Ancistrocladus benomensis Rischer \& G. Bringmann, spec. nov. - Fig. 1-3; Map 1}

Plantae omnio glabrae. Plantae juvenes erectae, non ramosae. Folia plantarum adultiorum in altitudine ca. $2 \mathrm{~m}$ terminaliter rosulate disposita, $23.5-61 \mathrm{~cm}$ longa et 5.7-11.5 $\mathrm{cm}$ lata, obovato-lanceolata, integerrima, basi revoluta et attenuata, apice rostrata, venis prominulis subtiliter reticulatis. Plantae adultae lignosae, scandentes in arboribus, ramis unilateraliter dispositis uncos circinales formantibus. Folia prope inflorescentias 10-22 $\mathrm{cm}$ longa et 3.5-6 cm lata, sessilia, lanceolata, apice obtusa ad acuta. Inflorescentia solitaria, terminalis, florendi tempore erecta, basaliter 1-3 bracteis circumstantibus. Bracteae longi-ellipticae, 2.2-3.1 mm longae, acuminatae. Cyma emergens ex foliorum rosula, laxa, 8-13 cm longa et 4-6 cm lata, 3-4-plo dichotome ramosa, flores caducos 50-70 gerens. Pedunculi 5-8 cm longi. Pedicelli 3.2-4.2 $\mathrm{mm}$ longi, inferne (prope basim) subarticulati et rubescentes. Gemmae (florum) rubrae, ovoideae, $2.8-3.5 \mathrm{~mm}$ longae et 2-2.5 mm latae. Flores 5-partitae, parvae, rubrae, florendi tempore diametro 7.4-8.8 $\mathrm{mm}$. Sepala 5, inaequalia, $1.7-2.7 \mathrm{~mm}$ longa et $0.7-1.1 \mathrm{~mm}$ lata, carnosa, margine subpapillato, extus glandulis crateriformibus $0-3$, tubo calycis breve, cupuliforme, lobis calycis late-ellipticis ad triangularibus, brevibus quam corolla, persistentibus, tempore fructus auctissimis. Petala 5, libera, subcontorta, 3.9-4.7 $\mathrm{mm}$ longa et $1.7-2.2 \mathrm{~mm}$ lata, longiora quam sepala, oblique elliptica, convexa, basin versus incrassata, margine revoluta, apice reflexa, emarginata, intus macula nigra praedita. Stamina 10, in verticillos 2 disposita, 


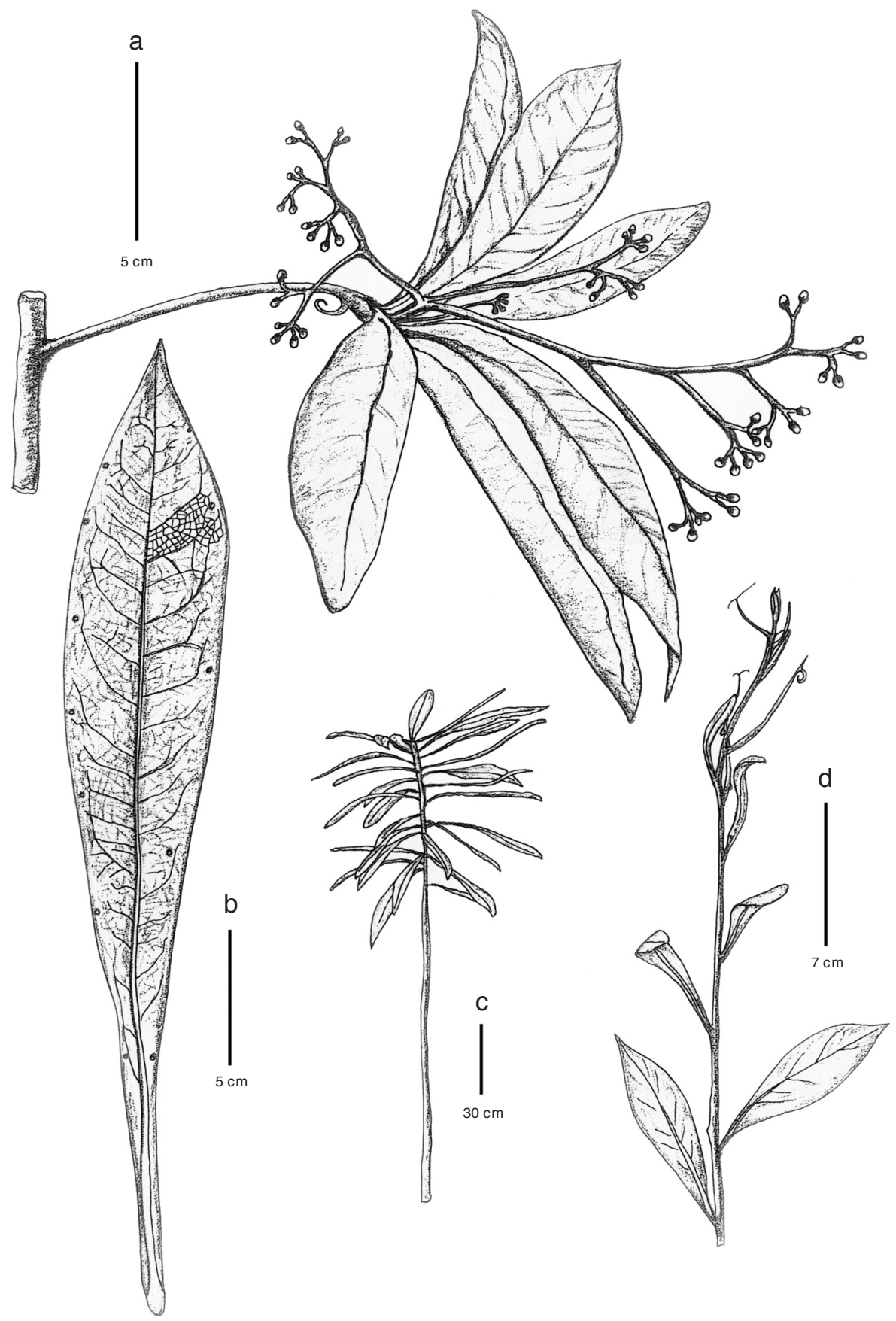

Fig. 1. Ancistrocladus benomensis Rischer \& G. Bringmann. a. Lateral branch with rosette leaves and inflorescence; b. leaf from main stem, venation in detail; c. sapling; d. shoot tip of climbing branch (a, b: holo; c, d: cultivated material; all: Heubl, M). 
alternatim inaequaliter longa; stamina longiora $1.1-1.5 \mathrm{~mm}$ longa, stamina breviora $0.7-1$ $\mathrm{mm}$ longa, filamentis basi incrassatis et petalis adnatis, antheris parvis, $0.3-0.5 \mathrm{~mm}$ longis. Granula pollinis 3-colpata, oblata ad suboblata, $35-42 \times 28-33 \mu \mathrm{m}$, spinulosa. Ovarium semi-inferum, conicum, stylis 3 , brevibus, $0.4-0.5 \mathrm{~mm}$ longis, stigmatibus parvis, capitatis. Fructus brunneus, sepalis tenuibus, coriaceis, inaequalibus, basi adnatis, majoribus $3,3.7-4.5 \mathrm{~cm}$ longis et $0.9-1.2 \mathrm{~cm}$ latis, minoribus 2 , obovatis ad ellipticis, $1.8-2.6 \mathrm{~cm}$ longis et $0.5-0.8 \mathrm{~cm}$ latis, fructus corpore obconico, $1-1.3 \mathrm{~cm}$ longo, diametro $0.6-0.8$ cm. - Typus: Rischer \& Wolf s.n. (holo M; iso KLU, No. KL4932) Malaysia, Pahang, Gunung Benom, 12 April 2000.

Plants entirely glabrous, saplings erect, unbranched, adult plants woody lianas climbing in trees, sympodial branches forming circinate unilateral hooks, lower ones getting woody. Leaves in c. $2 \mathrm{~m}$ height of older saplings arranged in terminal rosettes, sessile, obovate-lanceolate, $23.5-61$ by $5.7-11.5 \mathrm{~cm}$ (average 41.3 by $8.1 \mathrm{~cm}$ ), leathery, base attenuate, margin entire, revolute at the base, apex rostrate, about 12 glands distributed $3-5 \mathrm{~mm}$ from the margin on the lower surface, in dry state glands with a brown rim, midrib prominent beneath, veins finely reticulate, visible on both surfaces; leaves near inflorescences sessile, lanceolate, $10-22$ by $3.5-6 \mathrm{~cm}$, apex obtuse-acute, otherwise as described for the saplings' leaves. Inflorescence solitary, a terminal raceme, erect at anthesis subtended by $1-3$ basal bracts, bracts long-elliptic $2.2-3.1 \mathrm{~mm}$ long, acuminate. Cyme emerging from a leaf rosette, lax, $8-13$ by $4-6 \mathrm{~cm}, 3$ or 4 times dichotomously branched, bearing 50-70 caducous flowers. Peduncle 5-8 cm long. Pedicels $3.2-4.2$ $\mathrm{mm}$ long, weakly articulated near the base, with a red tinge. Flower buds red, ovoid, $2.8-3.5$ by $2-2.5 \mathrm{~mm}$. Flowers 5 -merous, small, bright red, $7.4-8.8 \mathrm{~mm}$ in diameter at anthesis. Sepals 5 , unequal, $1.7-2.7$ by $0.7-1.1 \mathrm{~mm}$, fleshy, margin weakly papil-

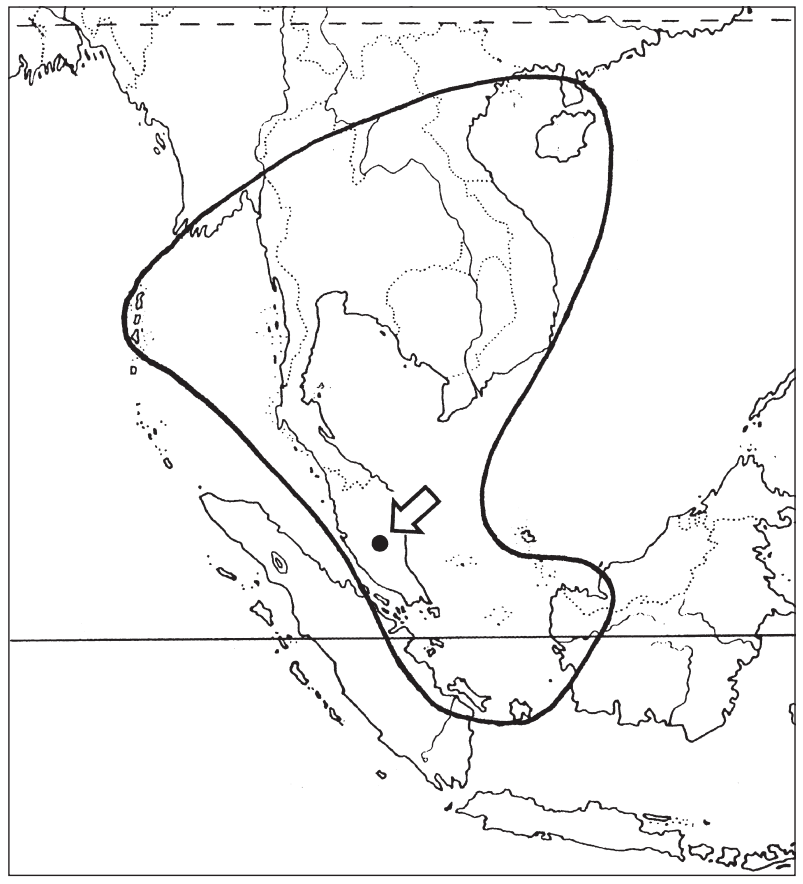

Map 1. Generalized distribution of the Ancistrocladus tectorius complex in South East Asia according to Van Steenis (1948). The locus classicus of Ancistrocladus benomensis is indicated (arrow). 

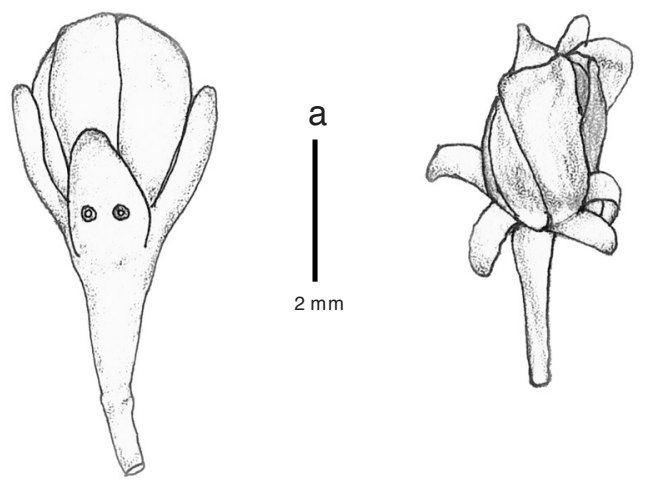

b
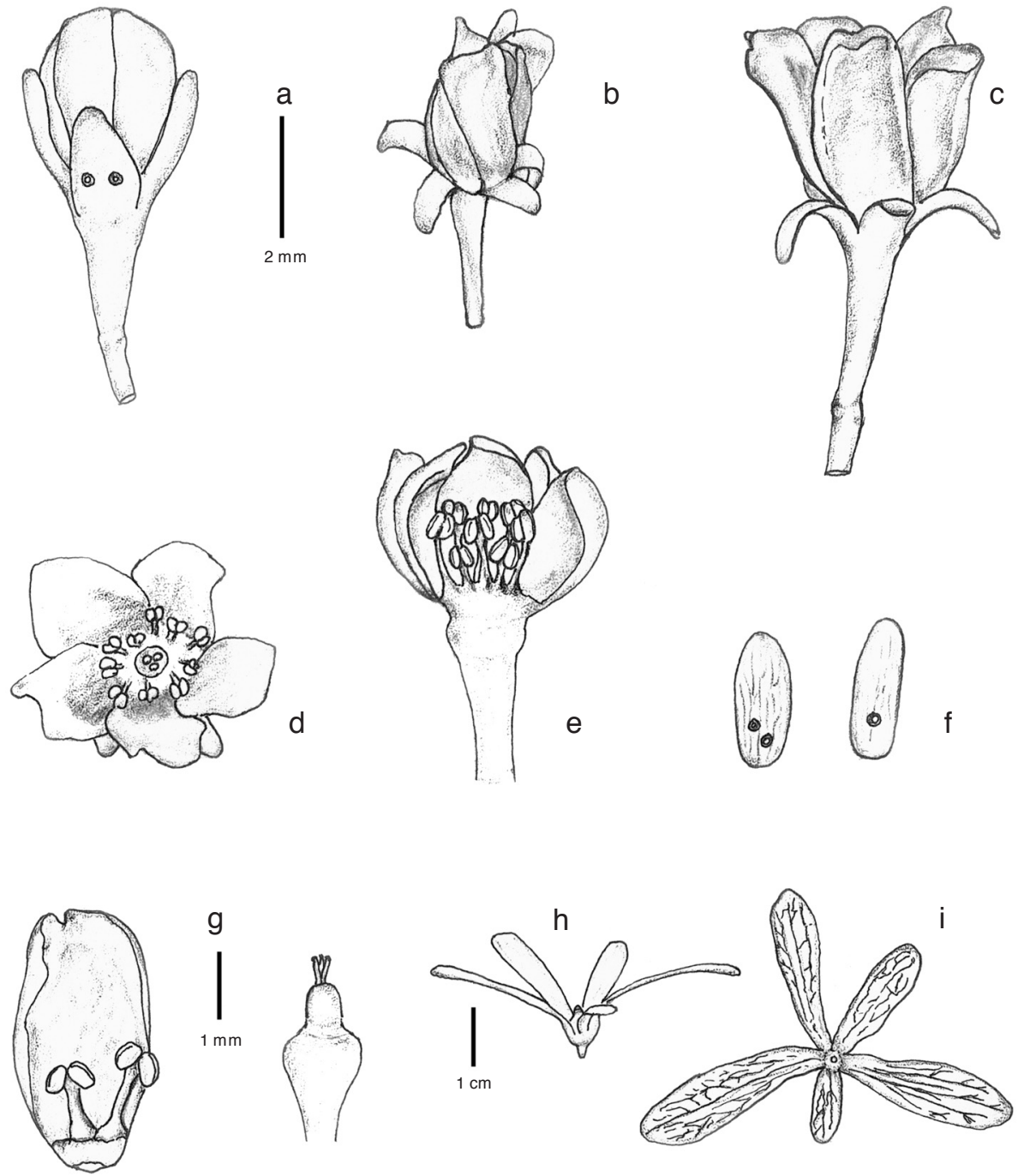

Fig. 2. Ancistrocladus benomensis Rischer \& G. Bringmann. a. Flower in bud; b. young flower with contorted petals; c. flower with view on reflexed sepals and petals; d. flower with 5 spots on inner surface of petals; e. flower longitudinally cut, part of perianth and stamens removed; f. sepals with glands; g. petal, inner surface with adnate stamens; h. ovary with three short styles; i. mature nut-like fruit with enlarged calyx-wings (a-g: holo; h, i: from locus classicus; all: Heubl, M).

late, on the outer surface of the lobes $0-3$ cup-shaped to crateriform prominent glands, calyx tube short, cup-shaped, calyx lobes broadly elliptic to triangular, shorter than the corolla (about half length), persistent and much enlarged in fruit. Petals 5, free, weakly contorted, $3.9-4.7$ by $1.7-2.2 \mathrm{~mm}$, longer than sepals, oblique-oval to elliptic, convex, thickened towards base, margin involute, on the tip finely toothed, reflexed and often inserted, with a contrasting black spot on the inner surface. Stamen 10, in 


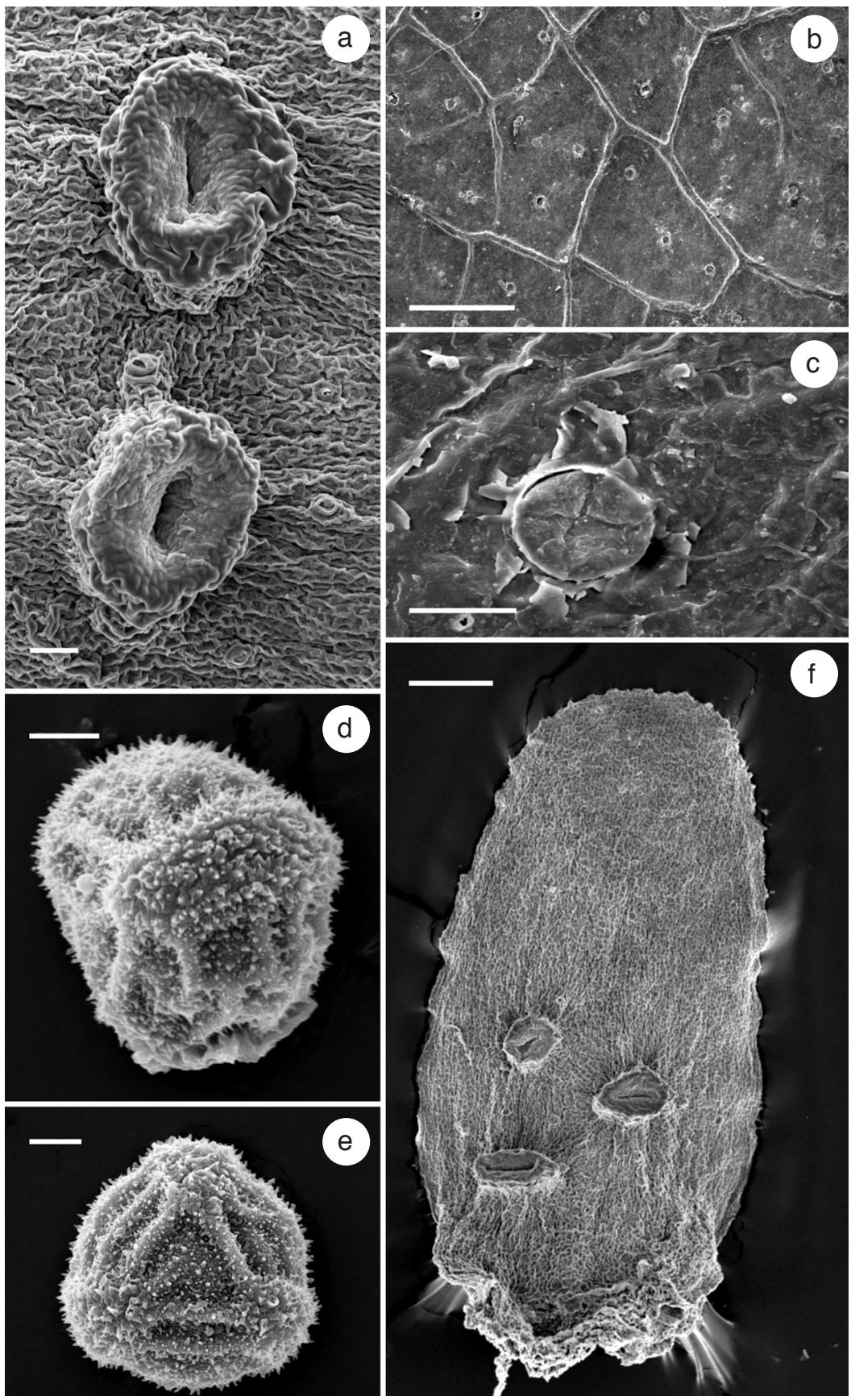

Fig. 3. Ancistrocladus benomensis Rischer \& G. Bringmann. Scanning electron micrographs (SEM) of fresh material. a. Glands in detail; b. abaxial leaf surface with glands; c. adaxial leaf surface with gland; d. pollen, equatorial view, showing colpus with ornamentation; e. pollen, polar view; f. sepal with three crateriform glands (a-c, f: cultivated material; d, e: holo; all: Heubl, M). 
2 whorls, alternately unequal, longer stamens $1.1-1.5 \mathrm{~mm}$ long, shorter stamens $0.7-1$ $\mathrm{mm}$ long, filaments broadened at the base, attached to the petals, anthers $0.3-0.5 \mathrm{~mm}$ with thecae clearly separated by the connective. Pollen grains 3-colpate (zonicolpate), oblate-suboblate, $35-42$ by $28-33 \mu \mathrm{m}$ (fresh material), exine ornamentation with spinules; colpi very distinct, with rounded ends, and covered with a membrane with a very coarse pattern. Ovary mostly inferior, upper part superior, conical, styles 3, short, 0.4-0.5 mm long, stigma capitate. Fruits brown, sepals papery-coriaceaous, upper surface glossy, towards the margins translucent against the light, unequal, margins revolute, veins clearly prominent beneath, only major ones visible above, the 2 shorter elliptic-obovate $1.8-2.6$ by $0.5-0.8 \mathrm{~cm}$, the 3 longer elliptic-obovate $3.7-4.5$ by $0.9-1.2 \mathrm{~cm}$, bases of all wings adnate to the fruit, margins decurrent half way along the fruit body forming a triangular furrow, fruit body obconical 1-1.3 cm long, 0.6-0.8 $\mathrm{cm}$ total diameter, the adnate basal remnants of the three styles forming a dome-shaped projection above the spreading wings, sometimes surrounded by a smooth annulus. Testa of seeds not corky, endosperm cerebriform-ruminate. Many fallen fruits bearing holes form emerged Curculionidae, nevertheless abundant seedlings near adult plants, germination cryptocotyledonous, epigeous.

Distribution - So far the species is only known from the type location Gunung Benom, Pahang, Malaysia.

Ecology - The species occurs from 500 to $1180 \mathrm{~m}$ above sea level on the slopes of Gunung Benom situated in the Kerau Game Reserve, which forms one of the last contiguous Dipterocarpaceae lowland forests in South East Asia.

Etymology - The species name refers to the type locality. 'Benom' is an old MonKhmer word for 'mountain'.

Note - Ancistrocladus benomensis is very similar to A. tectorius, which was described from Vietnam by De Loureiro (1780) as Bembix tectoria. Based on his short description and the notes on Loureiro's specimen by Moore \& Tandy (1927), the species from Peninsular Malaysia differs from A. tectorius in having alternate, sessile, obovate-lanceolate leaves, bright red flowers, 5 sepals, and a dichotomously branched inflorescence with 50-70 flowers. Ancistrocladus tectorius has opposite, cuneiform leaves with a short and broad petiole, pale flowers, 3 sepals, and a weakly branched inflorescence with only a few flowers.

\section{ACKNOWLEDGEMENTS}

We thank the directors and/or curators of the herbaria at K, KLU, M, and P for the opportunity to study type specimen and collections. We are grateful to Andrew Hurrell, Michael Wohlfarth, and Kristina Wolf for accompanying trips to Malaysia and the staff of the University of Malaya (Chemistry Department) for practical arrangements during the second excursion to Gunung Benom. The hospitality received in Thailand (by Dr. Thangonsak Joganurak and Voradol Chamchumroon from Royal Forest Department) with opportunities for field trips and studies, greatly facilitated our phytochemical and molecular studies. Furthermore, we would like to thank A. Kreiner and F. Thiele from the Botanical Garden of the University of Würzburg for the cultivation of A. benomensis, and T. Noll and I. Kajahn for their assistance in the documentation of the flowering process. The discovery of this new species resulted from an interdisciplinary project with focus on the chemotaxonomy and molecular phylogeny of the genus Ancistrocladus funded by the Deutsche Forschungsgemeinschaft (HE 2671 and BR 699/7-1) and by the Fonds der Chemischen Industrie. 


\section{REFERENCES}

Bringmann, G., M. Dreyer, H. Kopff, H. Rischer, M. Wohlfarth, H.A. Hadi, R. Brun, H. Meimberg $\&$ G. Heubl. In press. Ent-Dioncophylleine A and related dehydrogenated naphthylisoquinoline alkaloids, the first Asian Dioncophyllaceae-type alkaloids, from the 'new' plant species Ancistrocladus benomensis.

Bringmann, G., M. Dreyer, H. Rischer, K. Wolf, H.A. Hadi, R. Brun, H. Meimberg \& G. Heubl. 2004. Ancistrobenomine A, the first naphthylisoquinoline oxygenated at Me-3, and related 5,1'-coupled alkaloids, from the 'new' plant species Ancistrocladus benomensis. J. Nat. Prod. 67: 2058-2062.

Bringmann, G. \& L. Kinzinger. 1992. (+)-Ancistrocline, a naphthylisoquinoline alkaloid from Ancistrocladus tectorius. Phytochemistry 31:3297-3299.

Bringmann, G. \& F. Pokorny. 1995. The naphthylisoquinoline alkaloids. In: G. A. Cordell (ed.), The Alkaloids, Vol. 46: 127-271. Academic Press, New York.

Cheek, M. 2000. A synoptic revision of Ancistrocladus (Ancistrocladaceae) in Africa, with a new species from West Cameroon. Kew Bull. 55: 871-882.

Chen, Z., B. Wang, K. Qin, B. Zhang, Q. Su \& Q. Lin. 1981. Isolation and identification of the alkaloids from Ancistrocladus tectorius. Yaoxue Xuebao 16: 519-522.

De Loureiro, J. 1790. Genus XXVII. Bembix in: Flora Cochinchinensis, Bd. 1: 282-283. Ulyssipone, Typis et expensis Acad.

Foucher, J.P., J.L. Pousset, A. Cavé \& R.R. Paris. 1975. Sur les alcaloïdes de l'Ancistrocladus tectorius Loureiro du Laos. Pl. Med. Phytotherap. 9: 26-31.

Gereau, R.E. 1997. Typification of names in Ancistrocladus Wallich (Ancistrocladaceae). Novon 7: $242-245$.

Gilg, E. 1925. Ancistrocladaceae. In: H.G.A. Engler \& K.A.E. Prantl, Die natürlichen Pflanzenfamilien 2, 2: 589-592. Leipzig.

Harriman, N.A. 1987. Ancistrocladaceae. In: M.D. Dassanayake (ed.), Flora of Ceylon 6: 1-2. Amerind Publishing, New Delhi.

Manfredi, K.P., M. Britton, V. Vissieche \& L.K. Pannell. 1996. Three new naphthyldihydroisoquinoline alkaloids from Ancistrocladus tectorius. J. Nat. Prod. 59: 854-859.

Meimberg, H., H. Rischer, M. Dreyer, M. Sommaro, G. Bringmann \& G. Heubl. Submitted. The taxonomy of Ancistrocladaceae in South East Asia: A molecular approach.

Montagnac, A., H.A. Hadi, F. Remy \& M. Païs. 1995. Isoquinoline alkaloids from Ancistrocladus tectorius. Phytochemistry 39: 701-704.

Moore, S. \& G. Tandy. 1927. Notes on two species of Loureiro's Flora Cochinchinensis. J. Bot. 65: 279-281.

Nguyen, A.H., A. Porzel, H. Ripperger, G. Bringmann, M. Schäffer, R. God, T.V. Sung \& G. Adam. 1997. Naphthylisoquinoline alkaloids from Ancistrocladus cochinchinensis. Phytochemistry 45: $1287-1291$.

Ruangrungsi N., V. Wongpanich, P. Tantivatana, H.J. Cowe, P.J. Cox, S. Funayama \& G.A. Cordell. 1985. Ancistrotectorine, a new naphthalene-isoquinoline alkaloid from Ancistrocladus tectorius. J. Nat. Prod. 48: 529-535.

Tang, C.-P., Y.-P. Yang, Y. Zhong, O.-X. Zhong, H.-M. Wu \& Y. Fe. 2000. Four new naphthylisoquinoline alkaloids from Ancistrocladus tectorius. J. Nat. Prod. 63: 1384-1387.

Van Steenis, C.G.G.J. 1948. Ancistrocladaceae. In: C.G.G.J. van Steenis, Flora Malesiana 4: 8-10. Noordhoff-Kolff, Djakarta. 